\title{
The importance of harvest residue and fertiliser on productivity of Pinus patula across various sites in their first, second and third rotations, at Usutu Swaziland
}

\author{
Lindani Z. Mavimbela ${ }^{1 *}$, Jacob W. Crous ${ }^{2}$, Andrew R. Morris ${ }^{3}$ and Paxie W. Chirwa ${ }^{4}$
}

\begin{abstract}
Background: Concern is growing about the future of forestry productivity due to intensive nutrient removal, as a result of different harvesting operations. This study aimed to determine the effects on forest productivity when using different slash-retention scenarios with the recommended amounts of mineral fertiliser in Usutu forest. Usutu is a plantation forest that grows mostly softwood where the predominant species is Pinus patula Schiede ex Schltdl. \& Cham.

Methods: The first trial series (F) comprised of one trial located in each of five forest blocks. It was established in 1971 and compared the effects of various site preparation scenarios (slash removal, slash retention and cultivation) on the early growth of Pinus patula for adjacent first (F1R) and second rotation (F2R) sites (i.e. grassveld and clearfelled first-rotation sites). The second (S) trial series was re-established in April 1991 on exactly the same position as the first trial series, and involved second (S2R) and third rotation (S3R) sites. Three main treatments, standard pitting through harvest residue (control); manual pitting after removal of harvest residue and forest floor (cleared); and manual pitting and broadcast application of dolomitic lime $\left(2 \mathrm{t} \mathrm{ha}^{-1}\right)$ over the slash (lime), were undertaken in factorial combination with the application of phosphate and potassium fertiliser. The data reported here are for tree volume productivity across the five sites of the first trial series up to age 10 years and three of the five sites of the second trial series up to age 9 years.

Results: Slash removal decreased volume productivity by 9 and $13 \%$ in the F1R and F2R at 10 years of age and further by 21 and 33\% in S2R and S3R, respectively at 9 years of age. However, fertiliser application increased volume productivity by 14 and 15\% in the F1R and F2R at 10 years age and further by 18 and 10\% in the S2R and S3R, respectively at 9 years of age.
\end{abstract}

Conclusions: In order to sustain or increase productivity, it is recommended that harvest residue slash should be conserved and fertiliser containing phosphate and potassium be applied at planting at Usutu.

Keywords: Fertilisation, Slash removal, Slash retention, Type-2 response

\section{Background}

The nature of research into multiple forest rotations poses difficulties with some aspects like data collection, trial maintenance and records retrieval. In addition, the site and climate conditions can also vary over time and thus there have been only a small number of multiplerotation studies (Evans 1998). The aim of long-rotation

\footnotetext{
*Correspondence: vimbi28@gmail.com

${ }^{1}$ Department of Plant Production and Soil Science, University of Pretoria,

Private bag X20 Hatfield, Pretoria 0028, South Africa

Full list of author information is available at the end of the article
}

studies is to understand how forest site-establishment treatments affect growth patterns and productivity, which is essential for adopting sustainable management techniques (Jokela et al. 2010). Globally, attention has been given to some site-establishment practices that have negative impacts on long-term site productivity (LTSP). Whole-tree harvesting has been reported to export more nutrients from sites than conventional harvesting $(\mathrm{CH})$, where slash is retained, resulting in a decline in site productivity (Weber 1985; Olsson et al. 1996; Hyvönen et al. 2000; Egnell and Valinger 2003; 
Smaill et al. 2008; Eisenbies et al. 2009; Titshall et al. 2013). The conventional harvesting method applied at Usutu involved removing tree stems with bark from sites but not slash (Crous et al. 2007b) and is considered to have a less negative effect on site productivity than slash removal due to low nutrient content losses from stem wood (Mälkönen 1976; Olsson et al. 1996; Wall 2012). Harvest slash (foliage, branches and non-utilisable timber) is regarded as nutrient rich (Raison 1982; Wall 2012) so its retention on the forest floor results in no loss of growth and also increased volume production over time (Egnell 2011). This practice is followed in the case of Usutu where forest floors are rarely burnt (Crous et al. 2007b).

The retained slash on $\mathrm{CH}$ sites breaks down to form humus and helps maintain critical physical, chemical, and biological properties of soil (Eisenbies et al. 2009; Sayer 2006) that are crucial for the maintenance and supply of nutrients throughout multiple rotations (Raison 1982). Abiotic (water holding capacity, nutrients, soil temperature) site conditions have also been reported to have improved on CH sites (Raison 1982; Lundkvist 1983; Olsson et al. 1996; Smaill et al. 2008; Eisenbies et al. 2009; Palviainen et al. 2010; Titshall et al. 2013) as a result of maintenance of a humus layer (Egnell and Leijon 1999). Poor base saturation of calcium $(\mathrm{Ca})$ and magnesium $(\mathrm{Mg})$ due to slash removal on sites has been found to result in a decrease in soil $\mathrm{pH}$ (Olsson et al. 1996). Furthermore, retained slash cushions and protects soil against compaction and erosion, through improved infiltration (Sayer 2006; Eisenbies et al. 2009; Cortini et al. 2010) and also suppresses weeds (Titshall et al. 2013).

Southern African forestry soils are naturally low in fertility, occurring in old weathering surfaces in high rainfall areas (Olbrich et al. 1997). Low fertility is more prevalent on soils derived from quartzites, acid crystalline and sandstone rocks, as these often have potassium $(\mathrm{K})$ or phosphate $(\mathrm{P})$ as limiting nutrients. Timber harvesting at some sites has been reported to have caused an increase in the leaching of base cations, which can lead to soils becoming more acidic (Olbrich et al. 1997). Many tree species have been genetically improved to increase productivity, but this does not occur on soils deficient in P and K (Titshall et al. 2013) or Ca (Herbert and Schönau 1990). Site-specific, remedial fertiliser applications have been reported to overcome the effects of mineral nutrient deficiencies in soils, leading to yield improvement (Herbert and Schönau 1989; Herbert and Schönau 1990; Titshall et al. 2013). Conversely, Wall (2012) found that application of lime (calcium hydroxide) did not increase productivity when compared with retained slash. Although application of lime was found to increase biological activity within the soil (Baath and Arnebrant 1994), it promoted the breakdown and release of nutrients from humus (Marschner and Wilczynski 1991). Furthermore, lime is reported to have a negative effect on fine-root development (Persson and Ahlström 1990).
Woods (1990) observed that second-rotation (2R) Pinus radiata D.Don in South Australia had yellow, unhealthy foliage where slash was burnt during site preparation. Regional site assessments showed that the average growth rate of 18 to $20 \mathrm{~m}^{3} \mathrm{ha}^{-1}$ per annum declined by 25 to $40 \%$ in $2 \mathrm{R}$ stands across different locations. In subsequent studies, the cause of the decline was attributed to the loss of organic material due to burning of forest slash from the first rotation (1R) stands after clear felling. Yellowing of foliage may be symptomatic of nitrogen $(\mathrm{N})$ deficiency and the burning of slash may have resulted in the loss of nitrogen $(\mathrm{N})$ (Woods 1990). Fertiliser trials were conducted, and good tree-growth responses were obtained from high $\mathrm{N}$ application treatments, which indicated that $\mathrm{N}$ deficiency was most likely the cause of yield declines (Woods 1990). Similar concerns, initiated productivity research at the Usutu forest in 1968 in Swaziland (Evans 1975, 1996). The yield monitoring of successive rotations showed a $20 \%$ decline in productivity on the eastern part of Usutu, in the 2R crop (Evans 1978). Further investigation showed that the yield decrease occurred on soils derived from gabbro parent material, which had a high P-fixation capacity leading to low levels of plant-available $\mathrm{P}$ and $\mathrm{K}$, resulting in deficiencies of these nutrients (Morris: Soil fertility and long term productivity of Pinus patula in the Usutu Forest Swaziland, Unpublished). A review by Wall (2012) showed reductions in site productivity of $31-39 \%$ after clear-felling using the whole-tree harvesting technique. This harvesting technique reduced soil $\mathrm{P}$, which resulted in the most significant loss of yield. It also led to a $39 \%$ decrease in soil Ca followed by $\mathrm{K}$ and $\mathrm{Mg}$. A number of authors have reported on the need for appropriate fertiliser application in order to maintain soil timberproducing capacity (Mälkönen 1976; Jokela et al. 1991; Scott and Bliss 2012; Jokela and Long 2015). At Usutu, spot application of $20 \mathrm{~kg} \mathrm{ha}^{-1}$ of $\mathrm{P}$ and $\mathrm{K}$ fertiliser at planting and broadcast application of $75 \mathrm{~kg} \mathrm{ha}^{-1}$ of $\mathrm{P}$ and $\mathrm{K}$ fertiliser at first pruning at age 5 years, corrected the yield decline (Morris: Soil fertility and long term productivity of Pinus patula in the Usutu Forest Swaziland, Unpublished). Further research showed that a large proportion of $\mathrm{P}$ fertiliser was retained as residual $\mathrm{P}$ in the subsequent rotation as the inorganic $\mathrm{P}$ fertiliser was converted into organic P ( $\mathrm{P}_{\mathrm{o}}$ ) forms (Crous et al. 2007b, 2011a).

At Usutu forest, a trial comparing slash removal to slash retention and fertiliser application in the first and second rotations showed that slash removal at establishment resulted in unsustainable growth (Germishuizen 1979). Other studies have shown that this growth decline was caused by the loss of soil organic carbon (SOC) and nutrients (especially N) (Woods 1990), soil erosion and displacement (Titshall et al. 2013) and export of aboveground biomass (du Toit et al. 1999). 
Furthermore, removal of slash resulted in reduced soil moisture retention potential, low $\mathrm{pH}$ (Eisenbies et al. 2009), increased both soil temperature and bulk density (Smaill 2008) when compared with slash-retained plots (Sayer 2006). Short rotations also affect the mechanisms of nutrient supply and uptake balance because of changes in organic matter turnover (Mälkönen 1976; Raison 1982; Chen et al. 2000; Laclau et al. 2003). This occurs as a result of modified organic matter distribution and quality (Mälkönen 1976; Crous et al. 2011b). Hence, managing tree felling debris or slash during compartment reestablishment is considered important for maintenance of the nutrient cycle of the soil surface though mineralisation of harvest residue (Weber 1985; Perez-Batallon et al. 2001; Saarsalmi et al. 2010; Titshall et al. 2013). Therefore, retaining slash is considered beneficial in maintaining site productivity on nutrientpoor sites (Wall 2012), by promoting long-term maintenance of soil productivity (Carter and Foster 2004; Laclau et al. 2010). Crous et al. (2011b) suggested that larger quantities of $\mathrm{K}$ are exported from the site through stem bark and stem wood at $P$. patula harvest than at any other stage of the rotation. Retention of branches and foliage prevents nutrient export at about $37 \%$ of the total $\mathrm{N}, 13 \%$ of total $\mathrm{Ca}$ and $\mathrm{Mg}$ and $25 \%$ of total $\mathrm{P}$ and $\mathrm{K}$ of the aboveground biomass is in foliage (Hernández et al. 2009).

A reduction of 10 to $35 \%$ in tree height was recorded on 2R Pinus taeda L. and P. elliottii Engelm in the southern USA due to nutrient deficiency as a result of nutrient removal, particularly of $\mathrm{P}$, due to timber harvest (Tiarks et al. 1999; Rose and Shiver 2000). In Southern Africa, there is a need to understand the biogeochemical cycling processes for the maintenance of forest productivity as highlighted in studies conducted by du Toit and Scholes (2002), Scholes (2002), Crous et al. (2007b) and Dovey et al. (2011). This study was, therefore, aimed at investigating the effects of residue removal in comparison with residue retention and fertiliser application on tree growth over three rotations of two trials (F1R \& F2R and S2R \& S3R) in a pine plantation. Specifically, the study focused only on tree-based indicators of site productivity (tree height, tree diameter, basal area and stand volume).

\section{Methods}

\section{Site description}

Sappi Usutu forest plantation is situated $25 \mathrm{~km}$ southwest of Mbabane on the western Highveld of Swaziland. The land area covered is about 66,516 ha, of which 49,238 ha is productive (commercial) land, consisting of pine and eucalyptus species with $P$. patula being the dominant species. The soils at Usutu forest are generally red clay, derived from gabbro lithology, classified as
Oxisol (Soil Survey Staff 2006). A description of each site, indicating the compartmental underlying geology (Pallett: Forest land types of the Usutu Forest Swaziland, Unpublished) and soil sets namely: A9 (M-set), ${ }^{1}$ B17 or C9 (Q-set), ${ }^{2}$ D5 (T/Q-set) ${ }^{3}$ and E2 (N-set) ${ }^{4}$ (Murdoch 1968; Nixon 2006) is provided in Table 1. The Q/T-set site is on a ridge top and has a high stone content (Germishuizen 1979). Stony soils have a poor nutrients and moisture-storage ability (Macadam 1989). Several authors have stated that the soil at Usutu is generally highly leached, with low nutrient content and low cation exchange capacity (CEC), and moderate to strong acidic conditions (Morris 1995; Evans 1999; Crous et al. 2007a) , as shown in Table 2. The CEC range for Usutu forest sites was $0.8-2.7 \mathrm{cmol} \mathrm{\textrm {kg } ^ { - 1 }}$ (Germishuizen 1979). Similarly, Skinner et al. (2001) reported results of low CEC of $2.2 \mathrm{cmol} \mathrm{kg}^{-1}$ from kaolinite clay mineral soils found in forest soils of Washington State of the United States, North Island of New Zealand, and Kalimantan of Indonesia. The soil chemical analysis for the $0-8-\mathrm{cm}$ depth of all the first trial, second rotation (F2R) sites, show exchangeable aluminium $(\mathrm{Al})$ results which are above 1 cmolc $\mathrm{kg}^{-1}$ corresponding with lower $\mathrm{pH}$ values of sites (Table 2). Soil solutions with 1 cmolc $\mathrm{kg}^{-1}$ of exchangeable $\mathrm{Al}$ cause $\mathrm{Al}$ toxicity to plants (Akhtaruzzaman et al. 2014).

\section{First trial series}

The first trial series involved one trial located in each of five forest blocks (A9, B17, C9, D5 and E2; Table 1). It was designed to compare the effect of various sitepreparation scenarios on the early growth of Pinus patula for adjacent first (F1R) sites (i.e. grassveld) and second rotation (F2R) sites (i.e. clearfelled first-rotation sites). Three site preparation treatments were applied in factorial combination with a spot application of fertiliser. The site preparation treatments consisted of:

i) Removal of all harvest residue and forest-floor layer or grass to mineral soil followed by standard manual pit preparation (CLEARED).

ii) Standard manual pit preparation into remaining harvest residue or grassveld (CONTROL).

iii) Complete cultivation of the site by ploughing and rotavating to $20-\mathrm{cm}$ depth (CULTIVATED).

The fertiliser application supplied 180, 120 and $150 \mathrm{~kg} \mathrm{ha}^{-1}$ elemental N, P and K respectively. These nutrients were applied as granular limestone ammonium nitrate, double superphosphate and potassium chloride respectively (Germishuizen 1979). The trials were planted in 1971 at a $1.37 \times 1.37 \mathrm{~m}$ spacing (equivalent to 5330 stems per hectare (sph) with a plot size of six rows by six rows, which was a much higher planting density 
Table 1 Description of the underlying geology, soil set and additional comments related to the five sites used for the first trial

\begin{tabular}{|c|c|c|c|c|}
\hline Site & Underlying geology & Soil set description ${ }^{a}$ & Elevation ( $\mathrm{m}$ asl) & Comments \\
\hline A9 & Gabbro of the Usushwana complex & $\begin{array}{l}\text { M set: Soil deep red-orange apedal loams with weak } \\
\text { blocky structure in the argillic subsurface horizon. Friable } \\
\text { dry consistency. Base status low and weatherable } \\
\text { minerals absent or very rare. }\end{array}$ & 1082 & $\begin{array}{l}\text { Only site measured up to } \\
\text { rotation age, } 15 \text { years (Khoza, } \\
\text { Planning Manager Usutu, } \\
\text { personal communication, } \\
\text { 2013). }\end{array}$ \\
\hline B17 & \multirow{2}{*}{$\begin{array}{l}\text { Lochiel Hood granite with dolerite and minor } \\
\text { occurrences of Usushwana complex gabbro, } \\
\text { granitised gneiss and alluvium. }\end{array}$} & \multirow{2}{*}{$\begin{array}{l}\text { Q set: Soil grey loam which may be gravelly of } 30 \text { to } \\
50 \mathrm{~cm} \text { over deep friable gravelly loam. Gravel is almost } \\
\text { entirely quartz. Base status and weatherable minerals } \\
\text { content very low. }\end{array}$} & 1539 & \\
\hline C9 & & & 1393 & $\begin{array}{l}\text { Experienced severe hail } \\
\text { storm at age } 4 \text { years } \\
\text { (Germishuizen 1979). } \\
\text { Destroyed by fire in } 2007 \\
\text { (Khoza, Planning Manager } \\
\text { Usutu, personal } \\
\text { communication, 2013). }\end{array}$ \\
\hline D5 & $\begin{array}{l}\text { Lochiel Hood granite and granitised gneiss } \\
\text { with dolerite and minor amphibolite. }\end{array}$ & $\begin{array}{l}\text { T/Q set: Soil less than } 75 \mathrm{~cm} \text { deep soil reddish or } \\
\text { yellowish grey, loam sand to sandy loam over soft } \\
\text { weathering acid rock. Topsoil has weak or single grain } \\
\text { structure and loose consistence. Base status very low, } \\
\text { although content of weatherable feldspars may be } \\
\text { quite high. }\end{array}$ & 1403 & $\begin{array}{l}\text { Ridge top. Exposed and } \\
\text { subject to wind } \\
\text { (Germishuizen 1979). } \\
\text { Destroyed by hail in } \\
2002 \text { (Khoza, Planning } \\
\text { Manager Usutu, personal } \\
\text { communication, 2013). }\end{array}$ \\
\hline E2 & $\begin{array}{l}\text { Lochiel Hood granite, but also granitised } \\
\text { gneiss, dolerite intrusions and amphibolite. }\end{array}$ & $\begin{array}{l}\text { N set: Soil yellow brown loam to clay loam merging into } \\
\text { red clay loam to clay within } 100 \mathrm{~cm} \text {. Yellow topsoil may } \\
\text { have humic darkened surface and has very weak or } \\
\text { apedal structure and very friable dry consistence. Base } \\
\text { status low and weatherable minerals absent. }\end{array}$ & 1219 & \\
\hline
\end{tabular}

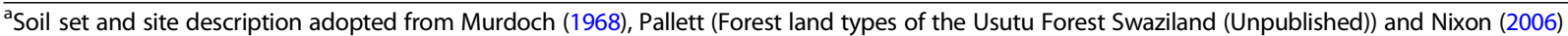

Table 2 Soil chemical characteristics of the five compartment soil sets, at the establishment of the first and second rotations of the first trial series; adapted from Germishuizen (1979)

\begin{tabular}{|c|c|c|c|c|c|c|c|c|c|c|c|}
\hline \multirow[t]{2}{*}{ Site } & \multirow[t]{2}{*}{ Rotation } & \multirow{2}{*}{$\begin{array}{l}\text { Depth } \\
(\mathrm{cm})\end{array}$} & \multicolumn{2}{|l|}{$\mathrm{pH}$} & \multirow{2}{*}{$\begin{array}{l}\text { Exchangeable } \\
\text { Al (cmolc kg } \\
{ }^{1} \text { ) }\end{array}$} & \multicolumn{3}{|c|}{ Exchangeable bases (cmolc kg-1) } & \multirow[t]{2}{*}{ CEC (cmolc $\left.\mathrm{kg}^{-1}\right)$} & \multirow[t]{2}{*}{$N(\%)$} & \multirow[t]{2}{*}{$\mathrm{OM}(\%)$} \\
\hline & & & $\mathrm{H}_{2} \mathrm{O}$ & $\mathrm{CaCl}_{2}$ & & $\mathrm{Ca}$ & $\mathrm{Mg}$ & K & & & \\
\hline \multirow[t]{4}{*}{ A9 (M-set) } & F1R & $0-8$ & 4.50 & 3.86 & 0.64 & 0.10 & 0.30 & 0.04 & 0.95 & 0.08 & 4.1 \\
\hline & F1R & $30-38$ & 5.00 & 4.18 & 0.30 & 0.30 & 0.60 & 0.19 & 1.50 & 0.12 & 4.1 \\
\hline & $F 2 R$ & $0-8$ & 4.12 & 3.72 & 1.16 & 0.10 & 0.35 & 0.06 & 2.00 & 0.06 & 4.6 \\
\hline & $F 2 R$ & $30-38$ & 4.30 & 3.92 & 0.78 & 0.10 & 0.10 & 0.04 & 1.20 & 0.08 & 4.1 \\
\hline \multirow[t]{4}{*}{ B17 (Q-set) } & F1R & $0-8$ & 4.50 & 3.95 & 0.78 & 0.20 & 0.40 & 0.12 & 1.70 & 0.20 & 7.1 \\
\hline & F1R & $30-38$ & 4.70 & 3.99 & 0.09 & 0.31 & 0.31 & 0.25 & 1.50 & 0.11 & 6.9 \\
\hline & $\mathrm{F} 2 \mathrm{R}$ & $0-8$ & 4.10 & 3.80 & 1.01 & 0.10 & 0.10 & 0.17 & 1.70 & 0.18 & 8.5 \\
\hline & $F 2 R$ & $30-38$ & 4.30 & 4.43 & 0.71 & 0.10 & 0.10 & 0.03 & 0.80 & 0.06 & 4.2 \\
\hline \multirow[t]{4}{*}{ C9 (Q-set) } & F1R & $0-8$ & 4.75 & 4.10 & 0.42 & 0.60 & 0.60 & 0.25 & 2.15 & 0.26 & 5.8 \\
\hline & F1R & $30-38$ & 4.72 & 3.98 & 0.48 & 0.20 & 0.40 & 0.06 & 1.30 & 0.08 & 3.6 \\
\hline & $F 2 R$ & $0-8$ & 4.18 & 3.62 & 1.16 & 0.20 & 0.50 & 0.12 & 2.25 & 0.18 & 5.5 \\
\hline & $F 2 R$ & $30-38$ & 4.18 & 3.78 & 1.01 & 0.10 & 0.30 & 0.05 & 1.20 & 0.08 & 3.5 \\
\hline \multirow[t]{4}{*}{ D5 (T/Q-set) } & F1R & $0-8$ & 4.50 & 3.95 & 0.70 & 0.10 & 0.40 & 0.11 & 1.60 & 0.18 & 6.2 \\
\hline & F1R & $30-38$ & 4.52 & 3.92 & 0.57 & 0.10 & 0.30 & 0.05 & 1.00 & 0.13 & 4.5 \\
\hline & $F 2 R$ & $0-8$ & 4.08 & 3.72 & 1.01 & 0.10 & 0.30 & 0.06 & 1.35 & 0.08 & 4.1 \\
\hline & $\mathrm{F} 2 \mathrm{R}$ & $30-38$ & 4.26 & 3.90 & 0.71 & 0.05 & 0.25 & 0.04 & 0.80 & 0.07 & 3.0 \\
\hline \multirow[t]{4}{*}{ E2 (N-set) } & F1R & $0-8$ & 4.80 & 3.98 & 0.42 & 0.08 & 0.08 & 0.14 & 2.70 & 0.14 & 7.2 \\
\hline & F1R & $30-38$ & 4.72 & 3.90 & 0.67 & 0.15 & 0.30 & 0.05 & 1.70 & 0.12 & 5.2 \\
\hline & $F 2 R$ & $0-8$ & 4.42 & 3.72 & 1.05 & 0.05 & 0.15 & 0.07 & 2.20 & 0.07 & 5.5 \\
\hline & $F 2 R$ & 30-38 & 4.30 & 3.85 & 0.69 & 0.05 & 0.25 & 0.04 & 1.50 & 0.08 & 4.4 \\
\hline
\end{tabular}


than the standard $2.7 \times 2.7 \mathrm{~m}$ spacing (equivalent to $1372 \mathrm{sph}$ ). At almost 4 years of age, mechanical thinning was conducted over the whole diameter distribution to decrease the stand density by $50 \%$ (to $2665 \mathrm{sph}$ ) (Morris: Trial series B43: Comparison of establishment method on first and second rotation sites, Unpublished). Estimates of standing volume were made in 1976, 1978 and 1982 at 4, 6 and 10 years age respectively (Morris: Trial series B43: Site preparation and fertilizer application at time of planting, part 1: Influence on volume increment, Unpublished).

\section{Needle sampling and nutrient analysis}

In July 1982, needle samples were collected from all five sites. A bulked sample from 15 trees was obtained by sampling three trees in each of the five replications for each treatment combination on each site. Mature needles formed during the previous spring or early summer period were collected from the upper half of the live crown. Samples were oven dried at $65{ }^{\circ} \mathrm{C}$ and ground in a Wiley Mill. Chemical analysis was conducted by the Malkerns Research Station of Swaziland. Total nitrogen was determined by Markham distillation with micro-Kjeldahl digestion method using concentrated sulphuric acid and salicylic acid with a selenium catalyst. The amount of nitrogen present in the form of ammonium ions was determined after filtration with hydrochloric acid. The elements $\mathrm{P}, \mathrm{K}, \mathrm{Ca}$ and $\mathrm{Mg}$ were determined on a sample dry ashed with magnesium nitrate and taken up in dilute hydrochloric acid. Phosphate was measured colorimetically as the molybdenum blue complex, potassium by flame photometer and calcium and magnesium by atomic absorption spectrometry (Morris: Trial series B43: Site preparation and fertilizer application at time of planting, Part 2: Influence on needle nutrient content, Unpublished).

\section{Second trial series}

The second trial series also involved one trial located in each of five forest blocks. This trial series was established in April 1991 at exactly the same position of the first trial series (Morris: Trial series B43: Comparison of establishment method on first and second rotation sites, Unpublished). Three site preparation treatments were applied in factorial combination with a spot application of $\mathrm{P}$ and $\mathrm{K}$ fertiliser. The cultivation treatment used in the first trial series could not be repeated due to the large number of stumps remaining. Therefore, lime was applied on the previously ploughed treatment plots with the objective of increasing the breakdown of slash on the forest floor. It should be noted that the lime treatment effects are confounded as their performance could have been influenced by residual effects associated with the previous cultivation treatment. The site preparation consisted of three treatments: i) Removal of all harvest residue and forest floor layer to mineral soil followed by standard manual pit preparation (CLEARED).

ii) Standard manual pit preparation into remaining harvest residue (CONTROL).

iii) Manual pitting and broadcast application of dolomitic lime $\left(2 \mathrm{tha}^{-1}\right)$ over the slash (LIME).

The fertiliser type used in the series was 0:1:1(17\%) PK and spot applied at $170 \mathrm{~g} \mathrm{seedling}^{-1}\left(72.3 \mathrm{~kg} \mathrm{ha}^{-1}\right.$ elemental $\mathrm{P}$ and $\mathrm{K}$, respectively). Nutrient depletion was accelerated by repeating the harvest-residue removal treatment. Each treatment was replicated five times within each of the rotation blocks. Trees were established at a spacing of $2 \mathrm{~m} \times 2 \mathrm{~m}$ (i.e. $2500 \mathrm{sph}$ ) to achieve a similar stocking rate as in the first trial series after thinning (Morris: Trial series B43: Site preparation and fertilizer application at time of planting, Part 2: Influence on needle nutrient content, Unpublished; Morris: Pitting of R143 trial sites. Internal Memorandum, Unpublished). Compartment D5 was destroyed by hail in 2002 and C9 was destroyed by fire in 2007 so only trial A9 was measured up to rotation age (S. Khoza, Planning Manager Usutu, personal communication, 2013). Therefore, results from 9-year-old trees at three sites (A9, C9 and D5) in the second trial series are reported here and are compared to the results from the first trial series on the same locations.

Soil analysis was not conducted at the end of the F1R and F2R or the S2R and S3R trials as the initial experiment did not focus on soil-based indicators of productivity. No information was recorded about the level of genetic improvement of material, but it is assumed to be unimproved material as most $P$. patula breeding programmes in South Africa only started in the 1990s.

\section{Tree growth measurements, calculations and statistical analysis \\ First trial series}

Tree height and diameter at breast height (DBH) were recorded at intervals in order to calculate estimated standing volume at ages 4, 6 and 10 years, using local volume-basal area relationships. Bark thickness of 4- and 6-year-old trees was determined using a bark gauge. Volume values for 10-year trees were extrapolated from destructive sampling of 120 trees from guard rows around each plot in 1982. A single tree per diameter range was selected from each plot for height measurement and data were fitted into the Schumacher Logarithmic Tree Volume Equation (Germishuizen (1979). Results were analysed statistically using two-way analysis of variance (ANOVA) to assess the effect of treatments on volume production and needle nutrient content. Correlations between 10-year growth and needle nutrient content 
were determined and analysed using multiple regression (Morris: Trial series B43: Site preparation and fertilizer application at time of planting, part 1: Influence on volume increment, Unpublished).

\section{Second trial series}

Tree height and DBH were recorded at 2-year intervals. Measurements within treatment plots were taken on 7 , 9, 11, 13 and 15-year-old trees within sub-plots. Subplots measuring $12.3 \mathrm{~m} \times 17.8 \mathrm{~m}$ set up to incorporate $6 \times 8$ rows with a spacing of $2 \mathrm{~m} \times 2 \mathrm{~m}$ between plots. The height and DBH of six randomly selected trees per plot were measured. The DBH was expressed conventionally as the quadratic mean $(\mathrm{QmDBH})$, which is the average stand diameter corresponding to tree arithmetic mean basal area (Curtis and Marshall 2000). Volume per hectare estimations were obtained from $\mathrm{DBH}$ and height measurements of six un-deformed live trees in each plot within the blocks using the Schumacher and Hall model (Bredenkamp 2000) shown in Eq. 1.

$$
\ln V=b 0+b 1 \ln (D B H+f)+b 2 \ln H
$$

Where:

$\ln =$ natural logarithm to the base $\mathrm{e}$

$V=$ stem volume $\left(\mathrm{m}^{3}\right.$, under-bark) usually to a $75-\mathrm{mm}$ tip diameter

DBH $=$ breast height diameter ( $\mathrm{cm}$, over-bark)

$f=$ correlation factor

$H=$ tree height $(\mathrm{m})$

$b 0=$ patula coefficient -13.4694

$b 1$ = patula coefficient 2.4396

$b 2$ = patula coefficient 1.3254

$f=$ patula coefficient 8

Basal area was calculated from the DBH of live trees in each plot using Eq. 2:

$$
\text { G_ha }=\frac{\pi\left(\frac{\mathrm{QmDBH}}{200}\right)^{2} \times \text { No.trees } / \text { plot }}{\text { Plot A (ha) }}
$$

Where:

G_ha = basal area per hectare

$\mathrm{QmDBH}=$ quadratic mean $\mathrm{DBH}$ in centimetres

No.trees/plot $=$ number of live trees per plot

Plot A (ha) $=$ plot area in hectares

Statistical analysis of the change in stocking rate and volume data was conducted using Genstat 15.1 software, using analysis of variance. ANOVA was undertaken using a factorial approach with site preparation by fertiliser as main treatment effects.

\section{Results}

First trial series

Tree volume production at 6 years of age on re-established (F2R) sites was not statistically different from the production on afforested grassland (F1R) sites (Germishuizen 1979). Cultivation significantly increased volume growth up to age 6 years, but subsequent growth to age 10 years was not increased (Morris: Trial series B43: Comparison of establishment method on first and second rotation sites, Unpublished). Site preparation and fertiliser treatments had a significant effect on volume production at most sites (Table 3a). There was no interaction between site preparation and fertiliser application (Table 3a).

The main treatments were not statistically significant on every site (Table 3a) but the absolute treatment responses were similar (Table 3b), resulting in significant responses in the mean treatment effects across the sites (Table 3a). The combination of fertiliser and slashretention treatment outperformed the no-fertiliser and slash-removed treatment combination (Table 3b). The mean treatment effect showed substantial increase in volume productivity for the control compared with the residue-removed treatment of $19 \mathrm{~m}^{3} \mathrm{ha}^{-1}$ and $28 \mathrm{~m}^{3} \mathrm{ha}^{-1}$ in the F1R and F2R respectively (Table 3b). Clearing all vegetation and/or harvest residue to mineral soil caused a substantial reduction in growth of up to 21\% at age 10 years (Morris: Trial series B43: Comparison of establishment method on first and second rotation sites, Unpublished). The high rate of fertiliser applied at planting across all sites produced substantial increases of $28 \mathrm{~m}^{3} \mathrm{ha}^{-1}$ at age 10 years in the F1R and $29 \mathrm{~m}^{3} \mathrm{ha}^{-1}$ in the F2R (Table 3b). The main treatment and fertiliser effects remained significant from 4 to 10 years (Table 4).

Yields for site-preparation treatments decreased in the following order: cultivation, control, and residue removed across all sites and both rotation cycles (Table 4b) The effects of site-preparation differed between F1R and F2R; the cultivation treatment in F1R increased volume production in relation to the control did not differ from the control at the age of 6 and 10 years in F2R (Table 4b). Fertiliser effects differed significantly across F1R and F2R at all ages (4, 6 and 10 years) as shown in Table $4 \mathrm{~b}$.

In general, the site-preparation treatments had little effect on needle nutrient concentration. The application of fertiliser increased the needle $\mathrm{P}$ and $\mathrm{K}$ levels and reduced $\mathrm{Mg}$ level on the F2R site (Table 5). It had no effect on $\mathrm{N}$ or Ca levels.

Across all treatments and sites, the amounts of $\mathrm{P}$ and $\mathrm{K}$ in needles showed a significant linear correlation with standing volume at age 10 years (Table 6). However, the strength of the correlation was low with a correlation coefficient of only 0.35 and 0.54 for $\mathrm{P}$ and $\mathrm{K}$ respectively. There was also a strong positive correlation between foliar $\mathrm{P}$ and $\mathrm{K}$ concentrations as well as between the $\mathrm{Ca}$ and $\mathrm{Mg}$ concentrations. 
Table 3 ANOVA summary of (a) significance level of five individual sites and (b) volume production per site main treatments at age 10 years, on the first and second rotations for the first (F) trial series established in 1971

\begin{tabular}{lllllll}
\hline Treatment & Site & & & & & \\
\cline { 2 - 6 } & A9 & B17 & C9 & D5 & E2 & Mean \\
\hline
\end{tabular}

(a) Significance level of sites

Level of statistical significance of F-test

First rotation (F1R)

$\begin{array}{lllllll}\text { Site preparation } & \text { n.s. } & * & \text { n.s. } & * & * * * & * * * \\ \text { Fertiliser } & \text { n.s. } & * * & * & * & * * * & * * * \\ \text { Interaction } & \text { n.s. } & \text { n.s. } & \text { n.s. } & \text { n.s. } & \text { n.s. } & \text { n.s. } \\ \text { Second rotation (F2R) } & & & & & & \\ \text { Site preparation } & * * & * * * & \text { n.s. } & * * * & * * & * * * \\ \text { Fertiliser } & * * * & \text { n.s. } & * * * & * * * & * * * & * * * \\ \text { Interaction } & \text { n.s. } & \text { n.s. } & \text { n.s. } & \text { n.s. } & \text { n.s. } & \text { n.s. }\end{array}$

(b) Site volume production

$$
\text { Volume production }\left(\mathrm{m}^{3} \mathrm{ha}^{-1}\right)
$$

First rotation (F1R)

$\begin{array}{lllllll}\text { Residue removed } & 220 & 186 \mathrm{~b} & 237 & 177 \mathrm{~b} & 166 \mathrm{C} & 197 \mathrm{C} \\ \text { Control } & 236 & 210 \mathrm{a} & 249 & 203 \mathrm{a} & 180 \mathrm{~b} & 216 \mathrm{~b} \\ \text { Cultivated } & 259 & 215 \mathrm{a} & 260 & 188 \mathrm{ab} & 203 \mathrm{a} & 225 \mathrm{a} \\ \text { LSD }^{0.05} \text { site preparation } & - & 21 & - & 16 & 10 & 9 \\ \text { No fertiliser } & 222 & 191 \mathrm{~B} & 237 \mathrm{~B} & 181 \mathrm{~B} & 161 \mathrm{~B} & 198 \mathrm{~B} \\ \text { Fertilised } & 254 & 216 \mathrm{~A} & 260 \mathrm{~A} & 197 \mathrm{~A} & 205 \mathrm{~A} & 226 \mathrm{~A} \\ \text { Grand mean } & 238 & 204 & 249 & 189 & 183 & 212 \\ \text { Second rotation (F2R) } & & & & & & \\ \text { Residue removed } & 186 \mathrm{~b} & 183 \mathrm{~b} & 237 & 154 \mathrm{~b} & 177 \mathrm{~b} & 187 \mathrm{~b} \\ \text { Control } & 237 \mathrm{a} & 221 \mathrm{a} & 239 & 182 \mathrm{a} & 195 \mathrm{a} & 215 \mathrm{a} \\ \text { Cultivated } & 237 \mathrm{a} & 227 \mathrm{a} & 251 & 193 \mathrm{a} & 205 \mathrm{a} & 222 \mathrm{a} \\ \text { LSD.05 site preparation } & 29 & 17 & - & 18 & 15 & 12 \\ \text { No fertiliser } & 193 \mathrm{~B} & 204 & 227 \mathrm{~B} & 158 \mathrm{~B} & 178 \mathrm{~B} & 195 \mathrm{~B} \\ \text { Fertilised } & 247 \mathrm{~A} & 217 & 257 \mathrm{~A} & 194 \mathrm{~A} & 206 \mathrm{~A} & 224 \mathrm{~A} \\ \text { Grand mean } & 220 & 210 & 242 & 176 & 192 & 208\end{array}$

Different letters indicate significant differences between means at the $5 \%$ level within each rotation. Means with no letters have no significant difference. Lowercase letters for site preparation and uppercase for fertiliser n.s. not significantly different

${ }^{*}=5 \%$ level, ${ }^{* *}=1 \%$ level, ${ }^{* * *}=0.1 \%$ level

\section{Second trial series}

The results for trees on individual sites at age 9 years indicate that volume production in S2R and S3R differed significantly among sites, as in the F1R and F2R trials. Site preparation had a significant effect on all sites on both rotations tested, except for the A9 S2R site (Table 7a). Soils of the three sites (A9, C9 and D5) all showed a positive response to fertiliser application on both the S2R and S3R sites even though only the A9 site was located on the gabbro (M-set). The absolute trend
Table 4 The ANOVA summary, (a) main treatment significance level and (b) volume production per main treatment across five sites over time for the first trial series established in 1971 on first and second rotation sites

\begin{tabular}{llll}
\hline Treatment & \multicolumn{3}{l}{ Age (years) } \\
\cline { 2 - 3 } & 4 & 6 & 10 \\
\hline
\end{tabular}

(a) Site significance level

Level of statistical significance of F-test

First rotation (F1R)

Site preparation

Fertiliser

Interaction

$\begin{array}{lll}* * * & * * * & * * \\ * * * & * * * & * * * \\ \text { n.s. } & \text { n.s. } & \text { n.s. }\end{array}$

Second rotation (F2R)

Site preparation

Fertiliser

Interaction

$\begin{array}{lll}* * * & * * & * * * \\ * * * & * * * & * * * \\ \text { n.s. } & \text { n.s. } & \text { n.s. }\end{array}$

(b) Site volume production

$$
\text { Volume production }\left(\mathrm{m}^{3} \mathrm{ha}^{-1}\right)
$$

First rotation (F1R)

$\begin{array}{llll}\text { Residue removed } & 24 \mathrm{~b} & 73 \mathrm{C} & 197 \mathrm{c} \\ \text { Control } & 27 \mathrm{~b} & 80 \mathrm{~b} & 216 \mathrm{~b} \\ \text { Cultivated } & 33 \mathrm{a} & 92 \mathrm{a} & 225 \mathrm{a} \\ \text { LSD }^{0.05} \text { site preparation } & 4.0 & 5.6 & 9 \\ \text { No fertiliser } & 25 \mathrm{~B} & 74 \mathrm{~B} & 198 \mathrm{~B} \\ \text { Fertilised } & 32 \mathrm{~A} & 89 \mathrm{~A} & 226 \mathrm{~A} \\ \text { Grand mean } & 28 & 81 & 212\end{array}$

Second rotation (F2R)

$\begin{array}{llll}\text { Residue removed } & 22 \mathrm{c} & 72 \mathrm{~b} & 187 \mathrm{~b} \\ \text { Control } & 27 \mathrm{~b} & 83 \mathrm{a} & 215 \mathrm{a} \\ \text { Cultivated } & 32 \mathrm{a} & 87 \mathrm{a} & 222 \mathrm{a} \\ \text { LSD }^{0.05} \text { site preparation } & 3.3 & 6.3 & 12 \\ \text { No fertiliser } & 23 \mathrm{~B} & 73 \mathrm{~B} & 195 \mathrm{~B} \\ \text { Fertilised } & 31 \mathrm{~A} & 88 \mathrm{~A} & 224 \mathrm{~A} \\ \text { Grand mean } & 27 & 81 & 208\end{array}$

Different letters indicate significant differences between the means at the $5 \%$ level within each rotation and age. Lowercase letters for site preparation and uppercase for fertiliser

n.s. not significantly different

$*=5 \%$ level, ${ }^{* *}=1 \%$ level, ${ }^{* * *}=0.1 \%$ level

was similar on all sites, which resulted in a significant fertiliser effect when the mean responses across all sites were analysed (Table 7a). On the A9 S3R site, a significant site preparation by fertiliser interaction was observed (Table 7a).

The slash-retention treatment (control) produced a larger increase in tree volume on Q-set soils compared with the other soil types in both S2R and S3R by 237 and $244 \mathrm{~m}^{3} \mathrm{ha}^{-1}$ respectively. Slash retention led to significantly increased tree volume than slash removal 
Table 5 The influence of fertiliser on needle nutrient concentration at age 10 years across all five sites of the first trial series established in 1971

\begin{tabular}{|c|c|c|c|c|c|c|}
\hline \multirow{2}{*}{$\begin{array}{l}\text { Nutrient in } \\
\text { needles (\%) }\end{array}$} & \multicolumn{3}{|c|}{ First rotation (F1R) } & \multicolumn{3}{|c|}{ Second rotation (F2R) } \\
\hline & No fertiliser & Fertiliser & Statistical significance of F-test & No fertiliser & Fertiliser & Statistical significance of F-test \\
\hline Nitrogen & 1.87 & 1.81 & n.s. & 1.65 & 1.75 & n.s. \\
\hline Phosphorus & 0.129 & 0.143 & $* *$ & 0.126 & 0.142 & * \\
\hline Potassium & 0.60 & 0.69 & $* * *$ & 0.52 & 0.59 & $* *$ \\
\hline Calcium & 0.21 & 0.22 & n.s. & 0.21 & 0.20 & n.s. \\
\hline Magnesium & 0.17 & 0.16 & n.s. & 0.18 & 0.15 & $* *$ \\
\hline
\end{tabular}

n.s. not significantly different

${ }^{*}=5 \%$ level, ${ }^{* *}=1 \%$ level, ${ }^{* * *}=0.1 \%$ level (adapted from Morris: Trial series B43: Site preparation and fertilizer application at time of planting, part 1: Influence on volume increment (Unpublished))

across almost all rotations and compartments-with only one exception of the $\mathrm{Q} / \mathrm{T}$-set soil in the $\mathrm{S} 2 \mathrm{R}$ (Table 7b). The fertiliser-application treatment also led to significantly increased tree volume across all sites and rotations.

The interaction of site preparation and fertiliser recorded on the M-set SR3 site was mainly driven by a significant increase in tree volume production when fertiliser was applied on the plots where harvest residue was removed (Fig. 1), whilst fertiliser application did not increase tree volume significantly on the other site preparation treatments.

The effects of residue removal, lime or fertiliser application on tree volume across the three sites remained significant over the 7- and 9-year assessments, but their interactions were not significant (Table 8a). The effect of residue removed was significantly lower than either the control or the lime treatments across sites and rotations at age 7 and 9 years (Table $8 \mathrm{~b}$ ). The fertiliser treatment exhibited significantly higher volume production than no fertiliser treatment in all three sites and S2R and S3R (Table 8b).

\section{Comparison of two trial series}

The results across all treatments on the same three sites indicated that there was no significant difference between F1R and F2R for plantings in 1971 as well as S2R and S3R established in 1991 (Fig. 2). The two trial series also demonstrated similar volume production despite the fact that they were established at different times and might have been subjected to different climatic conditions.

In the first trial series (1971) planting, the effect of cultivation of grassveld (F1R) decreased from 4 to 10 years, which resulted in no significant additional volume production by age 10 (Fig. 3). This is a Type-I response and commonly observed in silvicultural treatments that enhance resource availability at planting and shortly after planting. The fertiliser response remained constant over time and resulted in $12 \%$ more volume across all F1R sites by the age of 10 years. Fertiliser application in the following rotation (S2R, established in 1991) had a larger impact than in the previous rotation (Fig. 3). Removal of harvest residue had a negative impact on F1R growth that decreased over time. The negative impact of repeated residue removal was much greater in the following rotation and resulted in a $20 \%$ decrease in volume production by age 9 years (Fig. 3 ).

The effect of fertiliser at the age of 4 years produced $35 \%$ additional volume at F2R dropping to $20 \%$ at the age of 10 years. In the third rotation (S3R), the application of fertiliser had a smaller effect when compared to F2R, which only increased volume by $10 \%$ at the age 9 years (Fig. 4). The removal of harvest residue at the F2R site decreased volume production by more than $10 \%$ at age 10 years. In the following rotation (S3R), the repeated removal of harvest residue reduced volume production by more than $30 \%$ by age 9 years (Fig. 4).

Table 6 Correlation coefficients and statistical significance of relationship between needle nutrient concentration (\%) and volume production at age 10 years across all treatments and sites of the first trial series established in 1971

\begin{tabular}{|c|c|c|c|c|c|}
\hline & Timber volume at age 10 years & $\mathrm{Mg}(\%)$ & $\mathrm{Ca}(\%)$ & K (\%) & $\mathrm{P}(\%)$ \\
\hline$\overline{N(\%)}$ & 0.141 & 0.083 & 0.071 & 0.239 & 0.198 \\
\hline $\mathrm{P}(\%)$ & $0.349 * *$ & -0.118 & 0.054 & $0.493 * * *$ & \\
\hline K (\%) & $0.541 * * *$ & -0.023 & $0.318 *$ & & \\
\hline $\mathrm{Ca}(\%)$ & 0.182 & $0.415^{* * *}$ & & & \\
\hline $\mathrm{Mg}(\%)$ & 0.058 & & & & \\
\hline
\end{tabular}

${ }^{*}=5 \%$ level, ${ }^{* *}=1 \%$ level, ${ }^{* * *}=0.1 \%$ level (Morris: Trial series B43: Site preparation and fertiliser application at time of planting, Part 2: Influence on needle nutrient content (Unpublished)) 
Table 7 The ANOVA summary (a) significance level and (b) volume production per main treatment over three sites at age 9 years from the second and third rotation trials established in 1991

\begin{tabular}{|c|c|c|c|c|}
\hline \multirow[t]{2}{*}{ Treatment } & \multicolumn{4}{|l|}{ Site } \\
\hline & A9 & C9 & D5 & Mean \\
\hline \multicolumn{5}{|l|}{ (a) Site significance level } \\
\hline & \multicolumn{4}{|c|}{ Level of statistical significance of F-test } \\
\hline \multicolumn{5}{|l|}{ Second rotation (S2R) } \\
\hline Site preparation & n.s. & ** & * & $* * *$ \\
\hline Fertiliser & * & n.s. & n.s. & $* * *$ \\
\hline Interaction & n.s. & n.s. & n.s. & n.s. \\
\hline \multicolumn{5}{|l|}{ Third rotation (S3R) } \\
\hline Site preparation & $* * *$ & $* * *$ & $* * *$ & $* * *$ \\
\hline Fertiliser & $* * *$ & n.s. & n.s. & $* *$ \\
\hline Interaction & $* * *$ & n.s. & n.s. & n.s. \\
\hline \multicolumn{5}{|l|}{ (b) Site volume production } \\
\hline & \multicolumn{4}{|c|}{ Volume production $\left(\mathrm{m}^{3} \mathrm{ha}^{-1}\right)$} \\
\hline \multicolumn{5}{|l|}{ Second rotation (S2R) } \\
\hline Residue removed & 178 & $179 b$ & $113 \mathrm{~b}$ & $155 b$ \\
\hline Control & 209 & $237 a$ & $143 a b$ & $196 \mathrm{a}$ \\
\hline Lime & 224 & $231 \mathrm{a}$ & 157 a & $204 a$ \\
\hline Standard error of mean & 16.3 & 12.0 & 12.0 & 7.8 \\
\hline $\mathrm{LSD}_{0.05}$ for site preparation & 48.2 & 35.4 & 35.6 & 16.1 \\
\hline No fertiliser & 177 B & $207 \mathrm{~A}$ & $128 \mathrm{~A}$ & $170 B$ \\
\hline Fertilised & $230 \mathrm{~A}$ & $224 \mathrm{~A}$ & $149 \mathrm{~A}$ & $200 \mathrm{~A}$ \\
\hline Standard error of mean & 13.3 & 9.8 & 9.8 & 6.3 \\
\hline $\mathrm{LSD}_{0.05}$ for site preparation & 39.4 & 28.9 & 29.1 & 13.1 \\
\hline Grand mean & 204 & 215 & 138 & 185 \\
\hline \multicolumn{5}{|l|}{ Third rotation (S3R) } \\
\hline Residue removed & $176 b$ & $130 \mathrm{c}$ & $108 \mathrm{~b}$ & $138 \mathrm{~b}$ \\
\hline Control & $221 \mathrm{a}$ & $244 a$ & $155 a$ & $207 a$ \\
\hline Lime & $236 \mathrm{a}$ & $213 b$ & $170 \mathrm{a}$ & $206 a$ \\
\hline Standard error of mean & 5.3 & 10.3 & 7.1 & 5.7 \\
\hline $\mathrm{LSD}_{0.05}$ for site preparation & 15.6 & 30.4 & 21.0 & 13.1 \\
\hline No fertiliser & $195 \mathrm{~B}$ & $191 \mathrm{~A}$ & $139 \mathrm{~A}$ & $175 B$ \\
\hline Fertilised & $227 \mathrm{~A}$ & $200 \mathrm{~A}$ & $150 \mathrm{~A}$ & $192 \mathrm{~A}$ \\
\hline Standard error of mean & 4.3 & 8.4 & 5.8 & 4.6 \\
\hline $\mathrm{LSD}_{0.05}$ for site preparation & 12.8 & 24.8 & 17.1 & 10.7 \\
\hline Grand mean & 211 & 196 & 144 & 184 \\
\hline
\end{tabular}

Different letters indicate significant differences between the means at the $5 \%$ level within each rotation. Means with no letters have no significant difference. Lowercase letters for site preparation and uppercase for fertiliser

n.s. not significantly different

${ }^{*}=5 \%$ level, ${ }^{* *}=1 \%$ level, ${ }^{* * *}=0.1 \%$ level

\section{Discussion}

A significant decrease in the mean tree volume produced when slash was removed was observed across all sites in both the first trial series (F1R and F2R) and second trial series (S2R and S3R). Furthermore, over time, the negative impact (reduction in volume) of slash removal across all sites increased. In the first trial series at 10 years, volume loss was $19 \mathrm{~m}^{3} \mathrm{ha}^{-1}$ (9\%) and $28 \mathrm{~m}^{3} \mathrm{ha}^{-1}$ (13\%) for F1R and F2R respectively, while in the second trial at 9 years it was $41 \mathrm{~m}^{3} \mathrm{ha}^{-1}(21 \%)$ and $69 \mathrm{~m}^{3} \mathrm{ha}^{-1}$ (33\%) for S2R and S3R respectively. The results concur with those reported elsewhere (Egnell and 


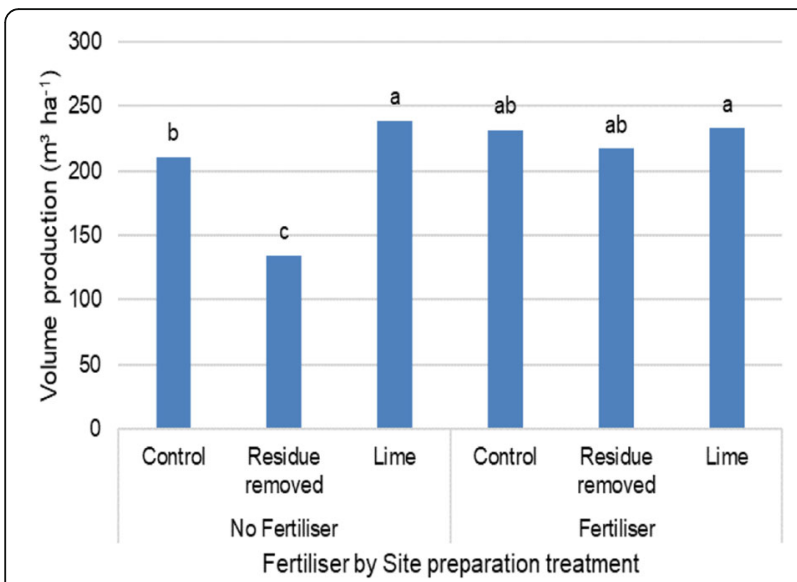

Fig. 1 Interaction between fertiliser and site preparation treatment on volume production at age 9 years on site $A 9$, third rotation plot

Leijon 1999, Egnell and Valinger 2003, Simpson et al. 2000,) of productivity loss of $11 \%$ for P. patula, $32 \%$ Pinus sylvestris L., 20\% P. sylvestris and 31.4\% Pinus elliottii at 10, 15, 24, and 3 years respectively. The productivity loss can possibly be attributed to the fact that harvest residue provides an important pool of nutrients to the successive crop. Hernández et al. (2009) stated that leaves contain about $37 \%, 13 \%$ and $25 \%$ of $\mathrm{N}$, Calcium (Ca) Magnesium (Mg) and $\mathrm{PK}$, respectively. Furthermore, slash from harvested timber, when left on the forest floor, is broken down and mineralised from its organic form to supply nutrients to ground vegetation and trees (Saarsalmi et al. 2010). In support of this, Wall and Hytönen (2011) stated that when slash is retained on forest floor, there is greater redepositing of nutrients mined by trees such as $\mathrm{K}, \mathrm{Ca}, \mathrm{Mg}$ and $\mathrm{P}$ than when slash is removed. Additionally, slash removal can have a negative effect on the supply of $\mathrm{N}$ and exchangeable base cations in the soil. Bark removal can result in the loss of $\mathrm{Ca}$ and P (Titshall et al. 2013). The differential decomposition rates of foliage, branches, bark and nonutilisable timber explains the continued nutrient supply (Saarsalmi et al. 2010). Other trials at Usutu have shown that the retention of organic matter plays an important role in the nutrient cycling of especially $\mathrm{P}$ (Crous et al. 2007b, 2008, 2011a). Germishuizen (1979) reported that site C9 (Q-set) was more productive, than A9 (M-set) and $\mathrm{D} 5(\mathrm{Q} / \mathrm{T}$-set) by 7 and $31 \%$ respectively in the F1R and by 18 and $44 \%$ in the F2R plot treatments with no fertiliser application respectively. Only in S2R was Q-set site highly productive by 17 and $62 \%$ than the $\mathrm{M}$-set and $\mathrm{Q} / \mathrm{T}$-set sites, and in the $3 \mathrm{R} \mathrm{M}$-set soils were highly productive by 2 and $40 \%$ than the Q-set and Q/T-set sites respectively. According to Germishuizen (1979), the location of the site with the lowest productivity, the Q/ $\mathrm{T}$-set site was on a ridge top, thus exposed and subjected
Table 8 The ANOVA summary (a) main treatment significance level and (b) volume production per treatment across three sites over time of a trial in the second and third rotation sites established in 1991

\begin{tabular}{ll}
\hline Treatment & Age (years) \\
\cline { 2 - 2 } 7 & 9 \\
\hline
\end{tabular}

(a) Main treatment significance level

Level of statistical significance of F-test

Second rotation (S2R)

Site preparation

Fertiliser

Interaction

**** $\quad$ ***

Third rotation (S3R)

Site preparation

Fertiliser

Interaction

n.s. n.s.

(b)

Second rotation (S2R)

$\begin{array}{lll}\text { Residue removed } & 102 \mathrm{~b} & 155 \mathrm{~b} \\ \text { Control } & 145 \mathrm{a} & 196 \mathrm{a} \\ \text { Lime } & 146 \mathrm{a} & 204 \mathrm{a} \\ \text { Standard error of mean } & 5.9 & 7.8 \\ \text { LSD }_{0.05} \text { for site preparation } & 16.6 & 21.9 \\ \text { No fertiliser } & 118 \mathrm{~B} & 170 \mathrm{~B} \\ \text { Fertilised } & 145 \mathrm{~A} & 200 \mathrm{~A} \\ \text { Standard error of mean } & 4.8 & 6.3 \\ \text { LSD } 0.05 \text { for site preparation } & 13.5 & 17.9 \\ \text { Grand mean } & 131 & 185\end{array}$

Third rotation (S3R)

$\begin{array}{lll}\text { Residue removed } & 91 \mathrm{~b} & 138 \mathrm{~b} \\ \text { Control } & 153 \mathrm{a} & 207 \mathrm{a} \\ \text { Lime } & 151 \mathrm{a} & 206 \mathrm{a} \\ \text { Standard error of mean } & 4.6 & 5.7 \\ \text { LSD }_{0.05} \text { for site preparation } & 13.1 & 16.1 \\ \text { No fertiliser } & 124 \mathrm{~B} & 175 \mathrm{~B} \\ \text { Fertilised } & 139 \mathrm{~A} & 192 \mathrm{~A} \\ \text { Standard error of mean } & 3.8 & 4.6 \\ \text { LSD } 0.05 \text { for site preparation } & 10.7 & 13.1 \\ \text { Grand mean } & 132 & 184\end{array}$

Different letters indicate significant differences between the means at the $5 \%$ level within each rotation. Lowercase letters for site preparation and uppercase for fertiliser

n.s. not significantly different

${ }^{*}=5 \%$ level, ${ }^{* *}=1 \%$ level, ${ }^{* * *}=0.1 \%$ level

to winds and also had a high stone content. Stony soils are known to have reduced nutrients and moisture storage ability (Macadam 1989). 


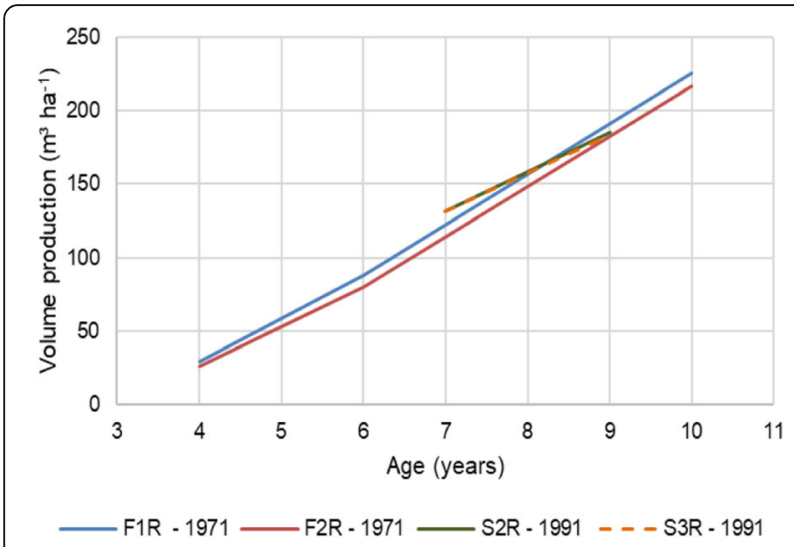

Fig. 2 Mean volume increment across all treatments over the three sites (A9, C9, D5) in the first (F1R) and second rotation (F2R) areas established in 1971, and the second (S2R) and third rotation (S3R) areas established in 1991

The cultivation treatment applied in the F1R had a significant effect on tree volume at age 10 years while in the F2R cultivation was only significant at age 4 years and showed no difference to the control at ages 6 and 10 years. This corresponded to all the initial silviculture land preparation trials that showed cultivation was beneficial during afforestation (planting of grassveld) but had no effect at re-establishment. According to du Toit et al. (2010), surface ploughing for the establishment of the F1R (grasslands) site resulted in improved productivity because of nutrient mineralisation and the physical break-down of the dense root mat normally formed on the grassveld. Ripping or subsoiling after the F1R had shown no significant improvement in site productivity (du Toit et al. 2010). The application of lime had no significant difference in productivity between the control

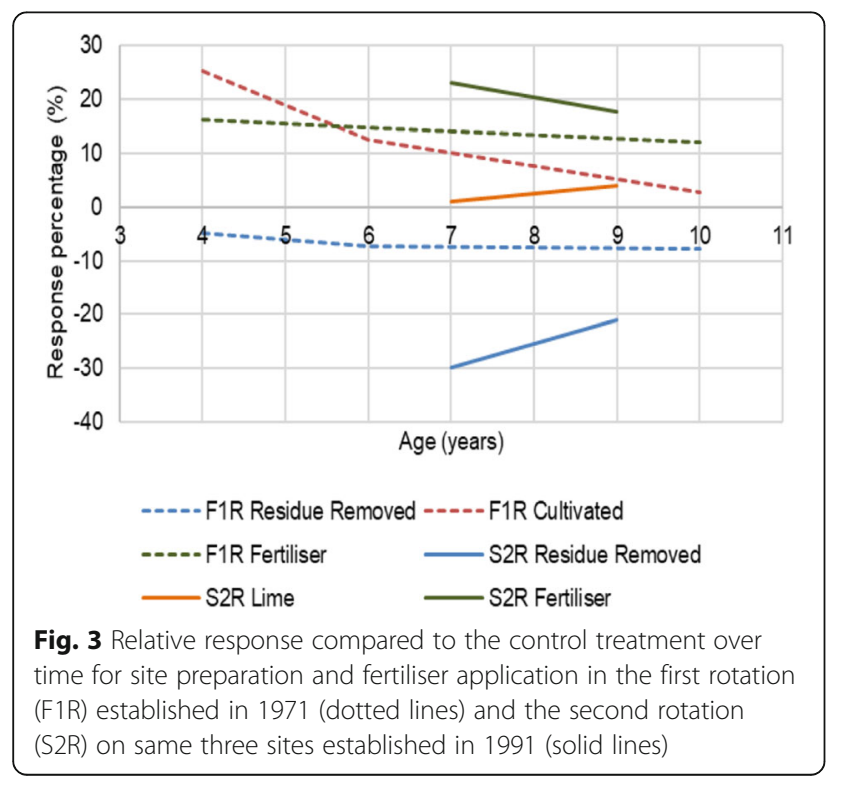

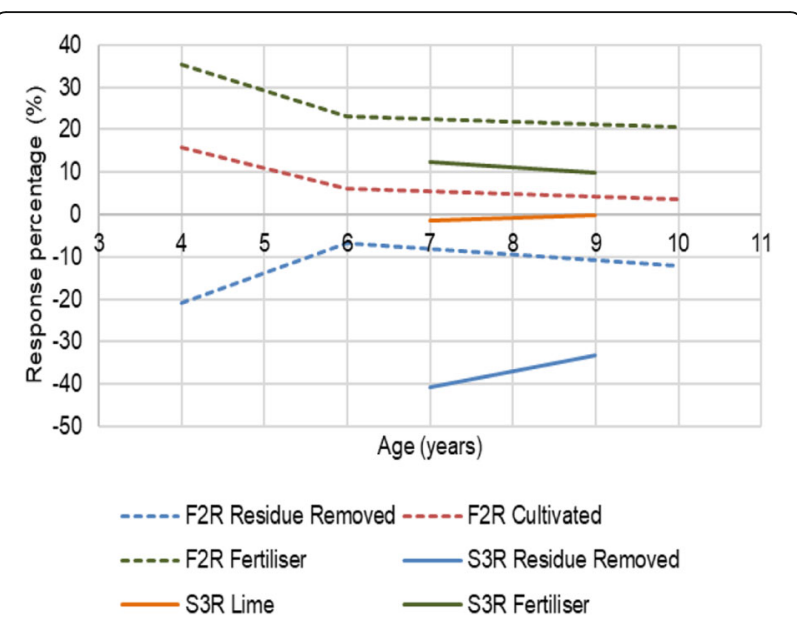

Fig. 4 Relative response compared to the control treatment over time for site preparation and fertilisation in the second rotation (F2R) established in 1971 (dotted lines) and third rotation (S3R) on same three sites established in 1991 (solid lines)

(slash retained) and lime treatments, similar to findings by Wall (2012). This was observed across all three sites (A9, C9, D5) of the second trial (S2R and S3R) at ages 7 and 9 years. In other studies, it has been demonstrated that lime increased biological activity (Baath and Arnebrant 1994), which helps further break down and release of nutrients from humus (Marschner and Wilczynski 1991). This effect might have released nutrients in abundance which could have resulted in more losses through leaching shortly after establishment. Furthermore, lime can have negative effects on fine root development, fine root distribution and mycorrhizal root tip development (Persson and Ahlström 1990), often resulting in a negative tree growth response (Wall 2012).

By the age of 10 years, fertiliser application across all sites increased volume production by $28 \mathrm{~m}^{3} \mathrm{ha}^{-1}(14 \%)$ and $29 \mathrm{~m}^{3} \mathrm{ha}^{-1}(15 \%)$ in the first trial series on F1R and F2R sites respectively. In the second trial series, the increased volume production at 9 years due to fertiliser application was $30 \mathrm{~m}^{3} \mathrm{ha}^{-1}(18 \%)$ and $17 \mathrm{~m}^{3} \mathrm{ha}^{-1}(10 \%)$ on S2R and S3R sites respectively. Likewise, Herbert and Schönau (1989) reported a 30 and $58 \%$ productivity improvement of $P$. patula at the age 6 and 8 years, while Donald and Glen (1974) reported an improvement of 12. 9 and $11.5 \%$ on Pinus radiata D.Don at age of 8 and 10 years after fertiliser application. The application of fertiliser resulted in a $11 \%$ and $15 \%$ increase in the needle $\mathrm{P}$ and $\mathrm{K}$ levels in the F1R and by 13 and $13 \%$ in the F2R respectively, while it reduced the $\mathrm{Mg}$ level by $17 \%$ in the F2R site. In other studies, it was shown that $\mathrm{P}$ fertiliser application significantly $(P<0.08)$ (Crous et al. 2007b) increased $P$ concentration in the needles (Donald and Glen 1974). Needles P and K were also highly correlated with each other. This made it difficult 
to determine the importance of these two nutrients. The needle nutrient content could only account for $30 \%$ of the variation in standing volume over the six treatments and 10 sites. This indicated that foliar analysis has its limitations and might not be an efficient management tool for providing fertiliser prescriptions when viewed alone (Morris: Trial series B43: Site preparation and fertilizer application at time of planting, part 1: Influence on volume increment, Unpublished).

In the first trial F1R, site response to fertiliser was highest in the N-set (E2) site with $44 \mathrm{~m}^{3} \mathrm{ha}^{-1}$ more productivity which denotes $27 \%$ gain, followed by the M-set (A9) with $32 \mathrm{~m}^{3} \mathrm{ha}^{-1}$ (14\%) gain. The greatest response to fertiliser application occurred at the site located on the M-set soil in F2R and also in S2R and S3R, with volume increases of $54 \mathrm{~m}^{3} \mathrm{ha}^{-1}$ (28\%), $53 \mathrm{~m}^{3} \mathrm{ha}^{-1}(30 \%)$ and $32 \mathrm{~m}^{3} \mathrm{ha}^{-1}(16 \%)$ respectively. Worth noting is that the M-set site was located on gabbro parent materials. A growth decline over rotations was previously observed by Evans (1978), which was later shown to be due to deficiencies in both $\mathrm{P}$ and $\mathrm{K}$ that were developing (Morris: Soil fertility and long term productivity of Pinus patula in the Usutu Forest Swaziland, Unpublished). Therefore, the site by fertiliser interaction on the M-set soil can possibly be explained by the significant increase in volume production when fertiliser was applied on the plots where harvest residue was removed in the S3R, whilst there were no interactions in the previous rotations. Similar responses were observed in other regional trials (Morris 2003; Crous et al. 2007a, 2009) and in trials outside Southern Africa (Fox 2000; Devine and Harrington 2007). The maintenance of high productivity by fertiliser indicated that its application caused a sustainable change in stand productivity due to inducement of trees to develop a root system that can exploit mineral nutrients and moisture on site at full potential (Herbert and Schönau 1990). This can be described as a Type-2 response (Snowdon 2002; Egnell 2011) or a Type-A response (Nilsson and Allen 2003).

\section{Conclusions}

The productivity loss associated with slash removal increased from $19 \mathrm{~m}^{3} \mathrm{ha}^{-1}$ (9\%) in F1R of the first trial series to $69 \mathrm{~m}^{3} \mathrm{ha}^{-1}$ (33\%) in S3R of the second trial series. This clearly indicated that the removal of slash from the forest floor during site preparation before planting of trees is a non-sustainable management option and should be avoided. A high rate of fertiliser applied at planting across all sites increased volume productivity by $28 \mathrm{~m}^{3} \mathrm{ha}^{-1}(14 \%)$ and $29 \mathrm{~m}^{3} \mathrm{ha}^{-1}(15 \%)$ at age 10 years of the first trial series on the F1R and F2R respectively compared to the un-fertilised treatment. Similarly, in the second trial series at age 9 years, fertiliser application improved productivity by $30 \mathrm{~m}^{3} \mathrm{ha}^{-1}(18 \%)$ and $17 \mathrm{~m}^{3} \mathrm{ha}^{-1}(10 \%)$ on the S2R and S3R sites respectively. Therefore, fertiliser application significantly improved volume productivity and maintained high productivity across all sites and rotations, which can be described as a Type- 2 response. Lime application had no effect on tree growth when compared with the control (slash retained) treatment. Therefore, it is not recommended for use at Usutu plantation. In order to sustain or increase productivity, it is recommended that harvest residue slash should be conserved and PK fertiliser be applied at planting at Usutu.

\section{Endnotes}

${ }^{1} \mathrm{M}$-set: Soils deep red, medium textured, occur on upper and mid-slopes and parental material is intermediate colluvium.

${ }^{2} \mathrm{Q}$-set: Topsoil sandy, overly poorly structured olive yellow calcareous sandy clay, occurs in bottom land positions or in drainage lines and parental material is sandstones and shales.

${ }^{3}$ T/Q-set: Dark greyish brown sandy clay loam which may contain soft and hard iron concretions, occurs in mid-slopes where drainage is impeded, and parental material is dolerite and basalt.

${ }^{4} \mathrm{~N}$-set: Soils brown, sandy-loam, occur on gentle lower slopes adjacent to river terraces and parent material is either basalt or dolerite (ancient alluvium).

\section{Abbreviations}

CH: Conventional harvesting; DBH: Diameter at breast height; LTSP: Longterm site productivity; QmDBH: Quadratic mean; SCO: Soil organic carbon

\section{Acknowledgements}

The authors would like to thank SAFCOL for the financial support through the University of Pretoria. The management of Sappi Usutu granted access to the trial data. Additional thanks to Mr. S Khoza for assistance in providing all the required data and information.

\section{Funding}

The South African Forest Company Limited funded my tuitions and cost involved from data collection to analysis, which covered travel, meals and accommodation.

Availability of data and materials

Please contact author to link you with Sappi Usutu the custodians of data.

\section{Authors' contributions}

LZM cleaned availed the data for analysis and wrote the manuscript. JWC coordinated field monitoring and oversaw the data analyses process. ARM contributed to the research design and data collection along with technical assistance. PWC facilitated and coordinated the process of acquiring data, its analysis partnership and writing of the paper. All authors read and approved the final manuscript.

\section{Authors' information}

LZM, MSc holder and currently PhD Candidate with University of Kwa-Zulu Natal.

JWC, PhD holder and working as Programme Leader - Land Management, Sappi Forests.

ARM, PhD holder working as the Acting Director and Research Manager, Institute for Commercial Forestry Research. 
PWC, PhD holder and a Professor at University of Pretoria under the Forest Science Postgraduate Programme and he is the SAFCOL Forest Chair.

\section{Ethics approval and consent to participate}

Not applicable.

\section{Consent for publication}

Not applicable.

\section{Competing interests}

The authors declare that they have no competing interests.

\section{Publisher's Note}

Springer Nature remains neutral with regard to jurisdictional claims in published maps and institutional affiliations.

\section{Author details}

${ }^{1}$ Department of Plant Production and Soil Science, University of Pretoria, Private bag X20 Hatfield, Pretoria 0028, South Africa. ${ }^{2}$ Sappi Forests, PO Box 473, Howick 3290, South Africa. ${ }^{3}$ Institute for Commercial Forestry Research, PO Box 100281, Scottsville 3209, South Africa. ${ }^{4}$ Department of Plant Production and Soil Science, University of Pretoria, Private bag X20 Hatfield, Pretoria 0028, South Africa.

\section{Received: 8 November 2017 Accepted: 20 March 2018} Published online: 17 April 2018

\section{References}

Akhtaruzzaman, M, Haque, M, Osman, K. (2014). Morphological, physical and chemical characteristics of hill forest soils at Chittagong University, Bangladesh. Open Journal of Soil Science, 4, 26-35.

Baath, E, \& Arnebrant, K. (1994). Growth rate and response of bacterial communities to $\mathrm{pH}$ in limed and ash treated forest soils. Journal of Soil Biology and Biochemistry, 26(8), 995-1001

Bredenkamp, B (2000). Volume and mass of logs and standing trees. Section 4.5 In DL Owen (Ed.), SAIF forestry handbook, (pp. 167-174). Pinetown: Southern African Institute of Forestry.

Carter, MC, \& Foster, DC. (2004). Prescribed burning and productivity in southern pine forests: A review. Journal of Forest Ecology \& Management, 191, 93-109.

Chen, GX, Yu, KW, Liao, LP, Xu, GS. (2000). Effect of human activities on forest ecosystems: $\mathrm{N}$ cycle and soil fertility. Nutrient Cycling in Agroecosystems, 57, 47-54

Cortini, F, Comeau, FG, Boateng, JO, Bedford, L. (2010). Yield implications of site preparation treatments for lodgepole pine and white spruce in northern British Columbia. Forests, 1, 25-48.

Crous, J, Morris, A, Scholes, M. (2007a). The significance of residual phosphorus and potassium fertiliser in countering yield decline in a fourth rotation of Pinus patula in Swaziland. Southern Hemisphere Forestry Journal, 69, 1-8.

Crous, J, Morris, A, Scholes, M. (2007b). Effects of residual phosphorus and potassium fertiliser on organic matter and soil nutrients in a Pinus patula plantation. Journal of Australian Forestry, 70, 200-208.

Crous, J, Morris, A, Scholes, M. (2008). Growth and foliar nutrient response to recent applications of phosphorus $(P)$ and potassium $(K)$ and to residual $P$ and $\mathrm{K}$ fertiliser applied to the previous rotation of Pinus patula at Usutu, Swaziland. Journal of Forest Ecology and Management, 256, 712-721.

Crous, J, Morris, A, Scholes, M. (2009). Effect of phosphorus and potassium fertiliser on tree growth and dry timber production of Pinus patula on gabbro-derived soils in Swaziland. Journal of Southern Forests, 71, 235-243.

Crous, J, Morris, A, Scholes, M. (2011a). Changes in topsoil, standing litter and tree nutrient content of a Pinus patula plantation after phosphorus and potassium fertilization. European Journal of Forest Research, 130, 277-292.

Crous, J, Morris, A, Scholes, MC. (2011b). Investigating the utilization of potassium fertilizer in a Pinus patula Schiede ex Schltdl. Cham. plantation. Journal of Forest Science, 57, 222-231.

Curtis, RO, \& Marshall, DD. (2000). Why quadratic mean diameter? Journal of Western Applied Forestry, 15(3), 137-139.

Devine, WD, \& Harrington, CA. (2007). Influence of harvest residues and vegetation on microsite soil and air temperatures in a young conifer plantation. Journal of Agriculture Forestry and Meteorology, 145, 125-138.

Donald, DGM, \& Glen, LM. (1974). The response of Pinus radiata and Pinus pinaster to N, P and K fertilizers applied at planting. South African Forestry Journal, 91(1), 19-28.
Dovey, SB, du Toit, B, de Clercq, W. (2011). Nutrient fluxes in rainfall, throughfall and stemflow in eucalyptus stands on the Zululand coastal plain, South Africa. Southern Forests, 73, 193-206.

du Toit, B, \& Scholes, MC. (2002). Nutritional sustainability of eucalyptus plantations: A case study at Karkloof, South Africa. Southern African Forestry Journal, 195, 63-72.

du Toit, B, Smith, C, Carlson, C, Esprey, L, Allen, R, Little, K (1999). Eucalypt and pine plantations in South Africa, Workshop proceedings, Site Management and Productivity in Tropical Plantation Forests (pp. 23-30). Bogor: Indonesia Center for International Forestry Research.

du Toit, B, Smith, CW, Little, KM, Boreham, G, Pallett, RN. (2010). Intensive, sitespecific silviculture: Manipulating resource availability at establishment for improved stand productivity. A review of South African research. Forest Ecology and Management, 259, 1836-1845.

Egnell, G. (2011). Is the productivity decline in Norway spruce following wholetree harvesting in the final felling in boreal Sweden permanent or temporary? Forest Ecology and Management, 261, 148-153.

Egnell, G, \& Leijon, B. (1999). Survival and growth of planted seedlings of Pinus sylvestris and Picea abies after different levels of biomass removal in clearfelling. Scandinavian Journal of Forestry Resources, 14, 303-311.

Egnell, G, \& Valinger, E. (2003). Survival, growth and growth allocation of planted scots pine trees after different levels of biomass removal in clear-felling. Forest Ecology and Management, 177, 65-74.

Eisenbies, MH, Vance, ED, Aust, WM, Seiler, JR. (2009). Intensive utilization of harvest residues in southern pine plantations: Quantities available and implications for nutrient budgets and sustainable site productivity. Bioenergy Research, 2, 90-98.

Evans, J. (1975). Two rotations of Pinus patula in the Usutu forest, Swaziland. Commonwealth Forestry Review, 54(1), 69-81.

Evans, J. (1978). A further report on second rotation productivity in the Usutu Forest, Swaziland- results of the 1977 assessment. Commonwealth Forestry Review, 57, 253-261.

Evans, J. (1996). The sustainability of wood production from plantations: Evidence over three successive rotations in the Usutu Forest, Swaziland. Commonwealth Forestry Review, 75(3), 234-239.

Evans, J. (1998). The suitability of wood production in plantation forestry. Unasylva, 192(49), 47-52.

Evans, J. (1999). Sustainability of plantation forestry: Impact of species change and successive rotations of pine in the Usutu Forest, Swaziland. Southern African Forestry Journal, 184, 63-70.

Fox, TR. (2000). Sustained productivity in intensively managed forest plantations. Journal of Forest Ecology and Management, 138(1), 187-202.

Germishuizen, PJ. (1979). The re-establishment of Pinus patula Schlecht. \& Cham. On a pulpwood rotation in Swaziland. MSc Thesis, University of Stellenbosch.

Herbert, MA, \& Schönau, APG. (1989). Fertilising commercial forest species in southern Africa: Research progress and problems (part 1). South African Forestry Journal, 151(1), 58-70.

Herbert, MA, \& Schönau, APG. (1990). Fertilising commercial forest species in southern Africa: Research progress and problems (part 2). South African Forestry Journal, 152(1), 34-42.

Hernández, J, del Pino, A, Salvo, L, Arrarte, G. (2009). Nutrient export and harvest residue decomposition patterns of a Eucalyptus dunnii maiden plantation in temperate climate of Uruguay. Forest Ecology and Management, 258, 92-99.

Hyvönen, R, Olssona, BA, Lundkvista, H, Staaf, H. (2000). Decomposition and nutrient release from Picea abies (L.) Karst. and Pinus sylvestris $L$. logging residues. Forest Ecology and Management, 126, 97-112.

Jokela, EJ, Allen, HL, McFee, WW. (1991). Fertilization of southern pines at establishment [chapter 14]. In ML Duryea, PM Dougherty (Eds.), Forest regeneration manual. Forestry sciences book series, 36, (pp. 263-277). Dordrecht: Springer.

Jokela, EJ, \& Long, AJ. (2015). Using soils to guide fertilizer recommendations for southern pines. [circular 1230]. Gainesville: University of Florida, Institute of Food and Agricultural Sciences (IFAS) Extension Service.

Jokela, EJ, Martin, TA, Vogel, JG. (2010). Twenty-five years of intensive forest management with southern pines: Important lessons learned. Journal of Forestry, 108, 338-347.

Laclau, J, Deleporte, P, Ranger, J, Bouillet, J, Kazotti, G. (2003). Nutrient dynamics throughout the rotation of eucalyptus clonal stands in Congo. Annals of Botany, 91, 879-892.

Laclau, J, Levillain, J, Deleporte, P, Nzila, JDD, Bouillet, J, Saint André, L, Versini, A, Mareschal, L, Nouvellon, Y, Thongo, MA, Ranger, J. (2010). Organic residue 
mass at planting is an excellent predictor of tree growth in Eucalyptus plantations established on a sandy tropical soil. Journal of Forest Ecology and Management, 260, 2148-2159.

Lundkvist, H. (1983). Effects of clear-cutting on the enchytraeids in a scots pine forest soil in Central Sweden. Journal of Applied Ecology, 20, 873-885.

Macadam, A. (1989). Effects of prescribed fire on forest soils., [research report 89001-PR]. Victoria: Ministry of Forests and Land. https://www.for.gov.bc.ca/hfd/pubs/docs/ Rr/R89001pr.pdf

Mälkönen, E. (1976). Effect of whole-tree harvesting on soil fertility. Silva Fennica, 10(3), 157-164

Marschner, B, \& Wilczynski, AB. (1991). The effect of liming on quantity and chemical composition of soil organic matter in a pine forest in berlin, Germany. Journal of Plant and Soil, 137(2), 229-236.

Morris, AR. (1995). Forest floor accumulation, nutrition and productivity of Pinus patula in the Usutu Forest, Swaziland. Journal of Plant and Soil, 168(1), 271278

Morris, AR. (2003). Site and stand age effects on fertiliser responses in Pinus patula pulpwood plantations in Swaziland. Southern African Forestry Journal, 199, 27-39.

Murdoch, G. (1968). Soils and land capability in Swaziland. Ministry of Agriculture bulletin 23-25. Soil map of Swaziland. National Soil Reconnaissance 19631967.

Nilsson, U, \& Allen, HL. (2003). Short and long-term effects of site preparation, fertilization and vegetation control on growth and stand development of planted loblolly pine. Journal of Forest Ecology and Management, 175, 367377

Nixon, DJ. (2006) Guide to the soils of the Swaziland sugarcane industry: A correlation of the Swaziland soil classification system with the south African binomial system. http://www.wossac.com/downloads/19837_Soils_of_the Swaziand_Sugar_Industry.pdf. Accessed 8 Mar 2018.

Olbrich, K, Christie, SI, Evans, J, Everard, D, Olbrich, B, Scholes, RJ. (1997). Factors influencing the long term sustainability of the south African Forest industry. Southern African Forestry Journal, 178, 53-71.

Olsson, BA, Bengtsson, J, Lundkvist, H. (1996). Effects of different forest harvest intensities on the pools of exchangeable cations in coniferous forest soils. Forest Ecology and Management, 4, 135-147.

Palviainen, M, Fine, L, Laiho, R, Shorohova, E, Kapitsa, E, Vanha-Majamaa, I. (2010). Carbon and nitrogen release from decomposing scots pine, Norway spruce and silver birch stumps. Forest Ecology and Management, 259, 390-398.

Perez-Batallon, P, Ouro, G, Macias, F, Merino, A. (2001). Initial mineralization of organic matter in a forest plantation soil following different logging residue management techniques. Annals of Forest Science, 58, 807-818.

Persson, H, \& Ahlström, K. (1990). The effects of forest liming on fertilization on fine-root growth. Journal of Water, Air, and Soil Pollution, 54(1), 365-375.

Raison, RJ, Khanna, PK, \& Crane, WJB. (1982). Effects of intensified harvesting on rates of nitrogen and phosphorus removal from Pinus radiata and Eucalyptus forests in Australia and New Zealand. New Zealand Journal of Forestry Science, 12(2), 394-403.

Rose, CE, \& Shiver, BD. (2000). A comparison of first and second rotation dominant and codominant heights for Flatwoods slash pine plantations. Plantation Management Research Cooperative, 2, 15-23.

Saarsalmi, A, Tamminen, P, Kukkola, M, Hautajärvi, R. (2010). Whole-tree harvesting at clear-felling: Impact on soil chemistry, needle nutrient concentrations and growth of scots pine. Scandinavian Journal of Forest Research, 25, 148-156.

Sayer, EJ. (2006). Using experimental manipulation to assess the roles of leaf litter in the functioning of forest ecosystems. Biological Reviews, 81, 1-31.

Scholes, MC. (2002). Biological processes as indicators of sustainable plantation forestry. Southern African Forestry Journal, 195, 57-62.

Scott, DA, \& Bliss, CM. (2012). Phosphorus fertilizer rate, soil P availability, and long-term growth response in a loblolly pine plantation on a weathered ultisol. Forests, 3, 1071-1085.

Simpson, JA, Xu, ZH, Smith, T, Keay, P, Osborne, DO, Podberscek, M. (2000). Effects of site management in pine plantations on the coastal lowlands of subtropical Queensland, Australia. Centre for International Forestry Research, 9, 73-81.

Skinner, MF, Zabowski, D, Harrison, R, Lowe, A, Xue, D. (2001). Measuring the cation exchange capacity of forest soils. Communications in Soil Science and Plant Analysis, 32, 1751-1764.

Smaill, SJ, Clinton, PW, \& Greenfield, LG. (2008). Postharvest organic matter removal effects on FH layer and mineral soil characteristics in four New Zealand Pinus radiata plantations. Forest Ecology and Management, 256, 558-563.
Snowdon, P. (2002). Modeling type 1 and type 2 growth responses in plantations after application of fertilizer or other silvicultural treatments. Journal of Forest Ecology and Management, 163, 229-244.

Soil Survey Staff (2006). Keys to soil taxonomy. $10^{\text {th }}$ ed. United States, Department of Agriculture, (p. 341). Washington, DC: U.S. Government Printing Office.

Tiarks, A, Klepzig, K, Sanchez, F, Lih, M, Powell, J, Buford, M. (1999). Role of coarse woody debris in the loblolly pine ecosystem. Biennial Southern Silvicultural Research Conference, 16(18), 238-242.

Titshall, L, Dovey, S, Rietz, D. (2013). A review of management impacts on the soil productivity of South African commercial forestry plantations and the implications for multiple-rotation productivity. Journal of Southern Forests, 75(4), 169-183

Wall, A. (2012). Risk analysis of effects of whole-tree harvesting on site productivity. Forest Ecology and Management, 282, 175-184.

Wall, A \& Hytönen, J. (2011). The long-term effects of logging residue removal on forest floor nutrient capital, foliar chemistry and growth of a Norway spruce stand. Journal of Biomass Bioenergy, 35, 3328-3334.

Weber, MG, Methven, IR, \& Van Wagner, CE. (1985). The effect of forest floor manipulation on nitrogen status and tree growth in an eastern Ontario jack pine ecosystem. Canadian Journal of Forest Research, 15, 313-318.

Woods, RV. (1990). Second rotation decline in P. radiata plantations in South Australia has been corrected. Journal of Water, Air and Soil Pollution, 54, 607-619.

\section{Submit your manuscript to a SpringerOpen ${ }^{\circ}$ journal and benefit from:}

- Convenient online submission

- Rigorous peer review

- Open access: articles freely available online

- High visibility within the field

Retaining the copyright to your article

Submit your next manuscript at $>$ springeropen.com 